Quarterly Journal of the Geological Society

\title{
On the Sandstones and Breccias of the South of Scotland of an age subsequent to the Carboniferous Period
}

R. Harkness

Quarterly Journal of the Geological Society 1856, v.12; p254-267.

doi: 10.1144/GSL.JGS.1856.012.01-02.34

\section{Email alerting service}

Permission request

Subscribe click here to receive free e-mail alerts when new articles cite this article

click here to seek permission to re-use all or part of this article

click here to subscribe to Quarterly Journal of the Geological Society or the Lyell Collection

\section{Notes}


marked with a red line all those places where the sinkings have hit the Coal or the "coal-measures"; with a green line those where the Mountain Limestone is reached, and with a blue line those where the sinkings are in the Silurian formation. We have indicated the extent of the several concessions, and have marked, by two red lines, the limits, as they are at present approximatively known, of the coalbasin of the "Pas de Calais." Lastly, we give you separately the number of the sinkings which we know have been made by various companies in the course of the last few years.

Paris, December 26th, 1855.

Note.-Several errors in the names of places occur in Plate V. MM. Degousée and Ch. Laurent, having seen a copy of the lithographed Map, which was prepared from the tracing forwarded to Mr. Tylor, have kindly transmitted another sketch-map (containing several new features of interest), with the local names very distinctly written. The following is a list of the more important errata :-

\begin{tabular}{ll|ll} 
For Marquises & read Marfuise. & For Harnes & read Hasnes. \\
- Hardinghem & - Hardinghen. & - Sollan & - Sallau. \\
- Nottinghen & - Lottinghen. & - Baches & - Raches. \\
- Fouquenottes & - Foucquexolle. & - Eupin & - Erchin. \\
- Vizernes & - Wizernes. & - Marchicourt & - Emerchicourt. \\
- Ellinghem & - Eblinghem. & - Menchicourt & - Monchecourt. \\
- Lapagnoy & - Lapuignoy. & - Auiche & - Aniche. \\
- Gounay & - Gesnay. & - Rilloy & - Tilloy. \\
- Bally-grenay & - Bully-grenay. & - Auzin & - Anzin. \\
- Anhay & - Annay. & &
\end{tabular}

3. On the Sandstones and Breccias of the South of ScotLAND* of an age subsequent to the Carboniferous Period. By R. Harkness, Esq., F.G.S.; Professor of Geology and Mineralogy, Queen's College, Cork.

IN a memoir " on the New Red Sandstone of the Southern Portion of the Vale of the Nith," published in vol. vi. of the Quart. Journ. Geol. Soc. (p. 389), I have given in detail the names of the localities where sections of these strata are exposed, also their dip at the several localities, and the connexion which exists between the different deposits composing what is termed the "New red sandstone" in this neighbourhood.

In describing the area occupied by this sandstone, I have been in error in supposing that, in the locality under notice, there is a connexion between the sandstone-beds of the Vale of the Nith and those of that portion of the Vale of the Annan in which the Corncocklemuir strata occur. A more perfect examination of the Dumfriesshire sandstones induces me to believe that there are five, if not seven distinct areas occupied by these deposits; and that the beds which appear in these several districts have an intimate connexion with each other, and are, for the most part, referable to the same geological age.

* See also Mr. E. W. Binney's paper "On the Permian Character of some of the Red Sandstones and Breccias of the South of Scotland," Quart. Journ. Geol. Soc., No. 46, p. 138.-Ev. 
Topography of the Sandstone areas.-To commence with the eastern side of the county, we have, occupying the S.E. extremity, a portion of the great deposit of sandstone which covers so large a surface of Cumberland. This has the usual aspect of the deposits in the latter county ; and, if we regard the sandstone of the country around Carlisle as Triassic, we have no alternative but to adopt the same nomenclature for this portion of the Dumfriesshire sandstones.

This area, commencing on the Solway Frith, in the parish of Cummertrees, and running in an E.N.E direction to the Liddle at Cannobie, I regard as Trias, and newer than the deposits to be more fully alluded to.

In the Vale of the Annan, about six miles to the north of the abovementioned area, the country is occupied by another area of sandstone, to which the name of the "Corncockle area" may be applied. Whether this can be connected with the deposits which occur on the east side of the River Annan, to the south and north of Moffat, is doubtful; and I am at present disposed to consider that in the higher portion of the Vale of the Annan there are three distinct areas, viz. the Corncockle,- the one which is seen in the form of a breccia in the streams immediately to the E. of Moffat, and to the S.E. at Bellcraig Linn, in the state of both sandstone and breccia,-and the third, filling up the head of the Annan in the district called the "Marquis of Annandale's Beef-tub."

To the N.W. of the north-western extremity of the Corncockle area, beyond several ridges of Lower Silurian mountains, there is found another spot where the sandstone presents itself, viz. to the S. of the farmhouse of Mitchell-Slack, in the course of the Capple Water. The area occupied by this is very small, probably not exceeding half a mile, if so much, in diameter; and the beds here have a brecciated character.

Westward from this last, we have another patch, of considerable size, occupying the east side of the Nith, from the Drumlanrig tunnel on the Glasgow and South-western Railway, to near Blackwood, having more than six miles in a $N$. and S. direction; and exceeding two miles in its greatest breadth.

To the south of this the "Dumfries area" appears, which has been already described. If the higher portion of the Vale of the Annan contains three areas of sandstone, we have scattered over the face of Dumfriesshire seven distinct patches of this substance; and these areas are well and widely separated from each other. If the higher portion of the Vale of the Annan contains only one patch, then we have five areas occurring under like circumstances.

Each of these several areas, with the exception of the one regarded as Trias, and the one which appears in the course of the Glasgow and South-western Railway immediately south of the tunnel (which may be termed the "Thornhill area"), has so far as can be determined Lower Silurian rocks for its margin. The other two are surrounded by Carboniferous rocks.

Sandstones and breccias of an age posterior to the Carboniferous are not confined in the South of Scotland to Dumfriesshire; we 


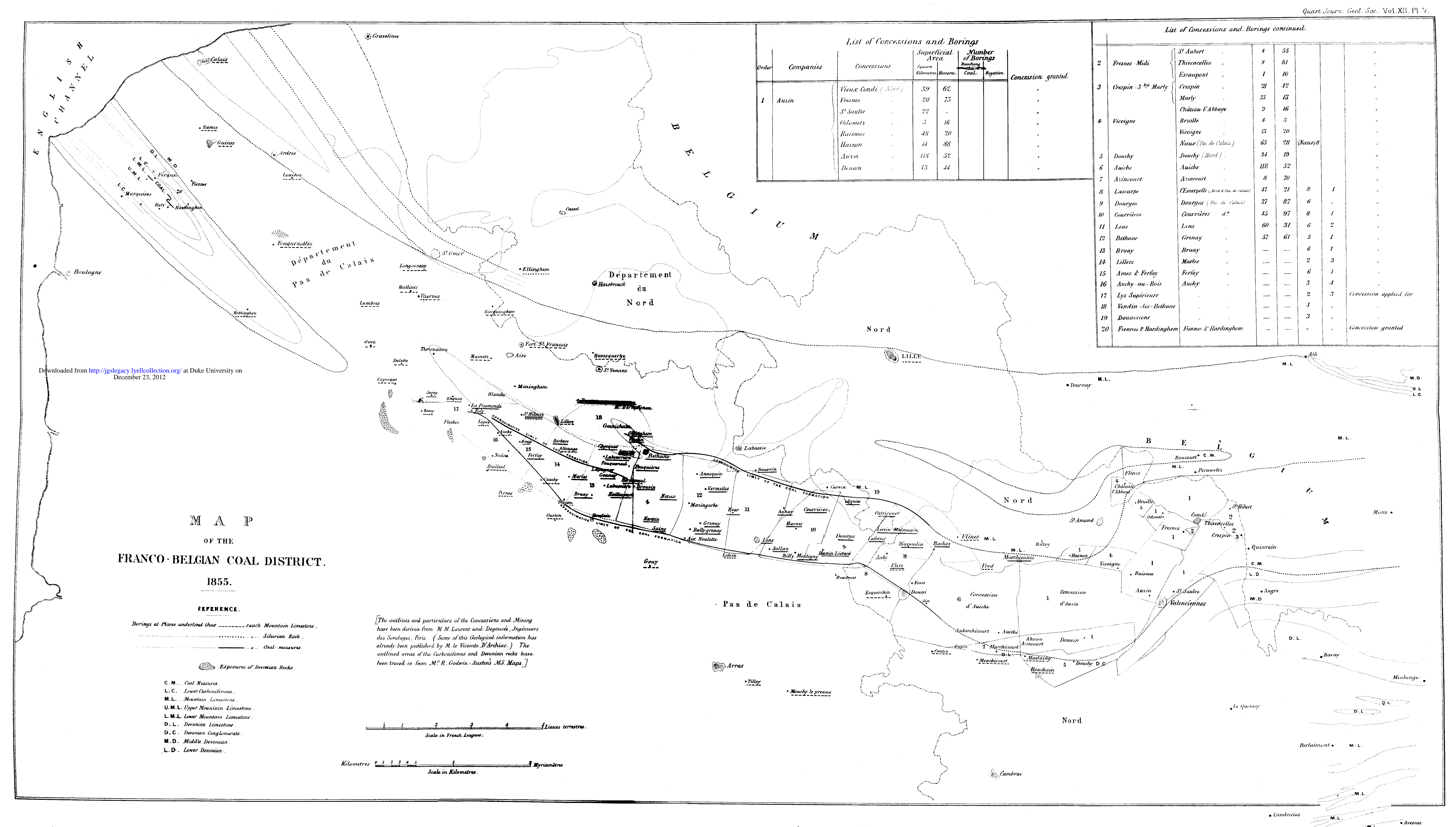


meet with deposits having the same characters, and apparently belonging to the same age, at and about Mauchline in Ayrshire; and, if we add this to the number, it gives us either six or eight patches of sandstones, covering several widely remote areas in the South of Scotland.

Physical Geology of the Sandstone-areas.-Besides the question as to the geological age of these patches, their position and isolation are matters of some importance, and there are certain circumstances connected with the physical geology of these strata which render them interesting.

As the Dumfries area has been already described, any matters of detail connected with this may be found in the memoir already alluded to. There are, however, certain phenomena or physical characters which are not there mentioned, and which should be noticed.

Corncockle Sandstone-area.-To commence with the Corncockle area,-this presents us with sandstones and breccias, but they have not the same relative arrangement as deposits of this nature have in the district around Dumfries. In the latter area we have a considerable thickness of sandstones, forming the lower portion of the deposits; these are succeeded by thick breccias (Craigs breccias); and above all we have sandstones, which are not extensively developed (Castledikes sandstone). In the Corncockle area there appear to be no equivalents of the breccias, nor the higher-lying sandstones; and the same remark, so far as I can ascertain, applies to all the other areas both in Dumfriesshire and Ayrshire. Breccias do occur in the other areas, but not under such circumstances as are presented in the Dumfries district.

In the most southern portion of the Corncockle area, at Dalton Hook, we have breccias exposed ; and these possess some features which are peculiar in Dumfriesshire. Here they were formerly wrought for lime; the calcareous matter occurring in the form of angular fragments of Carboniferous Limestone, characterized by the usual fossils : these angular fragments are associated with others derived from the Lower Silurians. Both the Carboniferous and the Lower Silurian formations are met with at about a quarter of a mile from the spot where this breccia has been worked. In this locality the strata dip N.N.W., at a slight angle.

Breccias of a somewhat similar nature are seen in the course of the Water of Milk, about two miles east from Dalton Hook; and at the northern end of the Lockerby railway-cutting the breccia also makes its appearance; but here the fragments seem to be exclusively of Lower Silurian origin, and the inclination is more towards the west. Beds of sandstone are met with in the course of the Dryffe Water; and in the small burn which runs from the N.E. near Nether Cleugh station, on the Caledonian Railway, beds of a similar nature are likewise found. In the course of the Upper-Cleugh Burn, immediately as the newer beds come in contact with the Lower Silurians, the former assume a brecciated character, like the deposit which is seen at the north end of the Lockerby Cutting; but at Upper Cleugh the 
matrix is of a softer nature. In the Ryecastle Burn, about two miles from Nether Cleugh station, where the two formations come in contact, the newer is found resting on the older, and consisting of sandstones, which dip toward the W.S.W. Here, at the junction of the two formations, breccias do not make their appearance.

At the north-eastern extremity of the Corncockle area the sandstones are well exposed. They occur in the course of the Annan at Johnston Bridge, and have a south inclination; and when we go west from this, we find them well developed in the course of the Kinnel Burn, about half a mile below St. Ann's Bridge. See Section, fig. 1. In this neighbourhood the best section of the sandstones and breccias is seen which this area affords.

\section{Fig. 1.-Section in the course of the Kinnel Water, Parish of} Johnstone, Dumfriesshire.

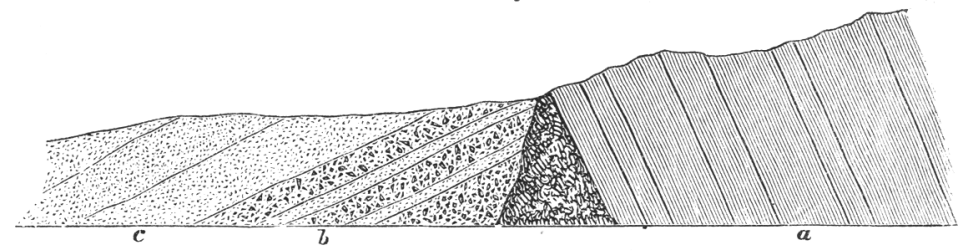

c. False-bedded sandstones.

b. Breccias and sandstones.

a. Silurian rocks.

A short distance above the foot-bridge over the Kinnel, near Elizatown, the Lower Silurians are seen with the sandstones almost in contact. These latter consist of thin beds of red sandstone, falsebedded, associated with breccias, the latter abounding to a greater extent than the former. The total thickness of these strata exceeds 100 feet; and they have above them deposits of false-bedded red sandstone, devoid of breccias; the whole dipping south at an angle of about $30^{\circ}$. Red sandstones of the same character occur in the course of the Mollin Burn. They are seen also on the road leading from the Moffat Road to Courance, and have a S.E. inclination. They also present themselves in the Burrans Burn, with a S.S.E. dip. And at the western extremity of this area the conglomerate occurs immediately under Kirkmichael Manse, abutting against the Lower Silurians*. To the south-east of this locality, immediately below the Water of Ae bridge, the sandstone likewise occurs; it is flaggy, and dips N.N.E. ; and near Trailflat, in the course of the Ae, it is also seen. From this last locality, I am not aware that the sandstones or breccias are anywhere exhibited until we reach Rammerscales; and here we have the strata dipping north; and at Smallholm the sandstone was formerly worked to a small extent, but the quarry is now filled up. Here likewise the northern dip obtained.

In the interior of this area the sandstone is well seen at Corncockle quarry, Templand Village quarry, Red Hall, and Lochbrow; the two latter quarries being now abandoned. In none of these four localities are the breccias seen; but the sandstones of the two quarries now

* See Section, Quart. Journ. Geol. Soc. rol. xi. p. 469. 
wrought, viz. Corncockle and Templand, differ materially from each other. The former consists of very regularly bedded red sandstone, easily worked; the latter of a hard red flag, coarser than the Corncockle beds, and remarkably durable. I know of no red sandstone which at all approaches the Templand flags in respect of hardness. In these two localities the strata dip to the W., at an angle exceeding $30^{\circ}$; and, as Templand lies a short distance to the S.W. of Corncockle, the beds which occur at this spot occupy a higher position than the Corncockle sandstone.

I learn from Sir William Jardine, that, like the Corncockle strata, the deposits which occur at Templand afford fossil footsteps.

There are some circumstances in connexion with the Corncockle area which are matters of interest. One of these is the directions of the inclinations of the strata in the several localities where the sandstones and breccias are exposed.

Whenever we find the newer and the older formations near each other, the former in all cases dips from the latter. On the eastern margins of the area we have a westerly dip, on the western an easterly dip, on the northern a southerly, and on the southern a northerly dip; and in the intermediate positions the same circumstances occur.

Had the area been circular, we should have had the dips converging to a central point ; but, as the form of the area is irregular, we have an approximation to this mode of arrangement. The Lower Silurian margins do not appear to present any evidence of the operation of those causes which have given to the sandstones and breccias their inclination ; for we have either a continuous N.N.W. or a continuous S.S.E. dip occurring all through the Silurians of Dumfriesshire. The cause of this peculiar mode of arrangement in the Corncockle area seems to have bcen local; and I can attribute it to no other circumstance than a subsidence in a small area, which has dragged down the strata towards it in all directions, and so produced a series of inclinations which always dip from the older formation.

Another circumstance of interest is the sequence of the deposits which form the sandstones and breccias. As concerns the latter, we have seen that it only occurs in certain spots along the margins of the area. When we have higher beds, these are seen to be falsebedded sandstones, as in the Kinnel Section; and in no case do we meet with any thick deposits of sandstone beneath the breccias, as is the case with the breccias of the Craigs in the Dumfries area. The mode of occurrence of the breccias would therefore lead to the inference, that these are the lowest deposits, - - that they are succeeded by a series of sandstones to which those wrought at Corncockle appertain, -and that the highest beds consist of the hard flags of Templand. We have therefore three groups,-1st, and lowest, breccias, with sandstones, more than 100 feet thick ; 2nd, sandstones, the thickness of which has not been ascertained, but which must be considerably thicker than the breccias ; and 3rd, hard flags, the thickness of which is not determined, but is probably less than that of the breccias.

The age of these several strata is also a matter of great interest; 
but this at present we are hardly in a position to discuss. At one time I was disposed to regard them as triassic, resting the conclusion on the character of the sandstones and the nature of the footprints found on them.

With regard to the latter, which are principally chelonian, I find these differ in the relative length of the toes from those which occur in the Trias sandstones of Western Point, Runcorn, Cheshire ; and, as Chelonians have existed during several geological epochs, too great importance may be attached to impressions of this Order. Under these circumstances, therefore, the triassic age of these strata is doubtful.

Sandstone-areas of the upper part of the Annan.- With regard to the two areas which occupy the east side of the River Annan, to the north of the Corncockle area, these consist of breccias with falsebedded sandstone; and beds of these characters are best seen in the Bell-Craig Linn, about four miles S.S.E. of Moffat. They appear to appertain to the lower strata of the more southern patch; and the inferior-lying conglomerates are well seen in the course of the Well Burn, from below Heathery Haugh to above Arch-bahk. In the most northern area, the sandstone is well exposed at Newton; and this is probably the lower portion of the false-bedded sandstone which rests upon the breccias, as seen in the course of the Kinnel Burn. It is on the eastern margin of these two areas that we have the beds exposed; and bere they are seen dipping from the Silurians. The western extremity of these patches is not seen, as the low ground is occupied by drift, and by gravel deposited by the River Annan. Where we have the newer strata exposed, they manifest themselves under the same circumstances as in the more southern area, viz. dipping away from the older deposits.

Sandstone-area of Mitchell-Slack.-As regards the little patch in the course of the Capple Water, below the farm-house of MitchellSlack, this is so small that little can be made of it, except that, from its brecciated nature, it appears to have affinity to the lower portion of the Corncockle series. It has a southerly inclination, dipping from the high hills which lie to the north. Its area cannot be made out owing to the drift which covers it, except in the spot before allnded to. This patch is, however, so closely surrounded on all sides by Lower Silurians, that the area occupied by it must be very small. Such a small isolated patch, surrounded on all sides by Silurian hills from 1000 to 2000 feet high, is a matter of considerable interest in connexion with physical geology.

Thornhill Sandstone-area. - The sandstone-area on the east side of the River Nith, around Thornhill, and occupying the lower portions of the parishes of Morton and Closeburn, is of considerable importance as concerns size; and its being, for the most part, surrounded by Carboniferous rocks renders this area different in its boundaries from the patches before-described.

We have better sections exposed here than in some of the other localities occupied by sandstones and breccias; and we can derive some iuformation from this area which the others do not afford.

The spot where we have the best sections of the strata of the 
Thornhill area is in the course of the Creechope Burn, at Creechope Linn, the scene of the retreat of Balfour of Burley in 'Old Mortality.' Here a small rapid streamlet has cut itself a deep channel among soft sandstones, leaving steep cliffs on either side. At the entrance of the Linn, a short distance above where the Creechope joins the Cample Burn, we have purplish flagstones, which belong to the Carboniferous age, dipping at N. $4^{\circ}$ S.E. at an angle of $15^{\circ}$; and the same flagstones are seen in the bed of the stream higher up the Linn, at a spot called the Sutor's Seat. The deposits, which at this spot occur immediately above the Carboniferous flagstones, cannot be seen owing to debris; but at about 9 feet above the flagstones purple clays make their appearance, with cream-coloured spots, devoid of lamination, and fracturing very irregularly. These have a thickness of about 6 feet; and above them are seen the soft red sandstones, attaining a considerable thickness, and very much false-bedded. See Section, fig. 2. In the purple clays I was unable to detect any

Fig. 2.-Séction at Sutor's Seat, Creechope Linn, near Thornhill, Dumfriesshire.

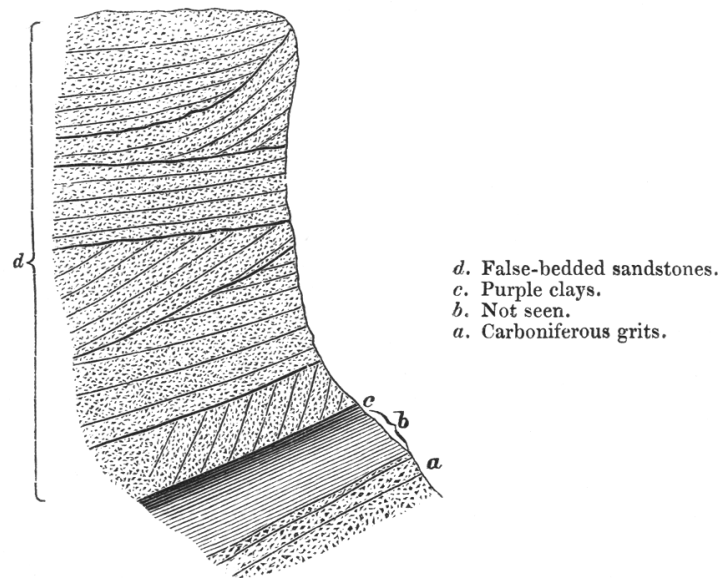

fossils. The sandstones extend through the whole of the Linn, and present the same false-bedded aspect, so much so that their apparent directions and dips are not to be depended on. At Gatelaw Bridge, about a mile north from Creechope linn, the sandstone is extensively worked; and is here also false-bedded, but not to the same extent as at the latter locality. Where the inclination is regular the dip is N.N.W., at an angle of $15^{\circ}$; and at a short distance, higher up the Cample Water, breccias are seen, which seem to underlie the sandstone of Gatelaw Bridge. Columnar basalt, with layers of amygdaloid, occurs further to the east than the breccias, and has furnished the latter with a considerable portion of their contents. 
In the course of the Glasgow and South-western Railway, we have the sandstones exposed twice in the cutting between the Thornhill and Carron Bridge Stations, and one of these exposures presents a troughing of the beds. North of Carron Bridge Station, in the cutting at the south entrance of the Drumlanrig tunnel, we have the sandstones and accompanying strata well exposed. The beds here dip south, at an angle of about $12^{\circ}$; and besides sandstones we have breccias of an interesting character. The south end of the tunnel consists of amygdaloidal trap ; and on the south side of this we have the breccias composed of fragments of the igneous rocks in great abundance ; and these, with the associated sandstones, dip from the amygdaloids. See Section, fig. 3. At the north end of the tunnel,

Fig. 3.-Section at the South Entrance of Drumlanrig Tunnel, Carron Bridge Station, Dumfriesshire.

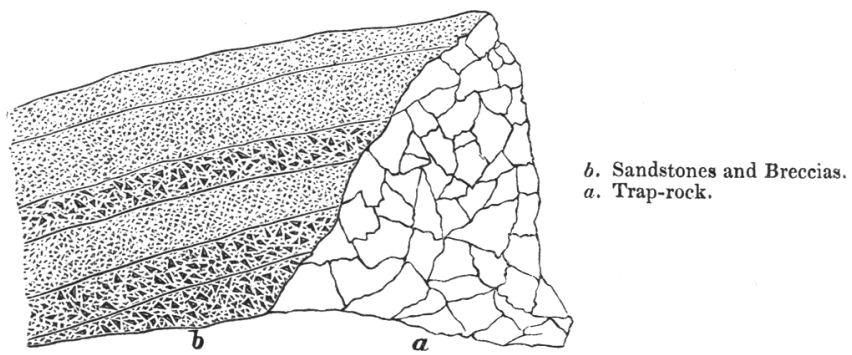

we have variegated Carboniferous grits, dipping S.S.E., at an angle of $25^{\circ}$; and through these grits the igneous rock has burst.

The occurrence of igneous rocks here, and the relations which these bear to the Carboniferous beds, as well as their connexion with the newer sandstone strata, are subjects of interest, as we are enabled, to some extent, to derive information concerning the age of the latter; and this is more important as we shall find in another district the sandstones and breccias occurring under like circumstances. The relations which exist between these several rocks show that the outbursts of trap were anterior to the deposition of the sandstones and breccias; and this does not appear to be a mere local occurrence, but tends to support the inference that the Coal-fields of the centre of Scotland had not only been deposited, but had been subjected to all those violent disturbances, and outbursts of igneous matter, which are so prevalent among them, before the deposition of the sandstones and breccias.

As in the other areas of sandstone which are found in Drumfriesshire, we have no proofs that the causes which disturbed them have affected the Silurians surrounding this area; but the intermediate Carboniferous strata partake to a great extent of the influences of the forces which have disturbed the newer formation. From the appearance of the breccias in the lower portion of these deposits, I am disposed to consider them as the equivalents of the lower and middle portion of the Corncockle series. 
Sandstone-area of Mauchline, Ayrshire.-We have now to leave Dumfriesshire and go to near the centre of the adjoining county Ayrshire. In this district, around Mauchline, there is another patch of red sandstone and breccias exhibited. About a quarter of a mile to the south of the Mauchline Station this sandstone is worked. It possesses all the features which characterize the false-bedded sandstones above the breccias in the several Dumfriesshire areas, and seems to be of considerable thickness. About half a mile further south, at Ballochmoyle, in the course of the Water of Ayr, we have a beautiful section exhibiting these sandstones and the strata upon which they repose.

Immediately above the bridge over the Railway the red sandstones $\operatorname{dip}$ N. $50^{\circ} \mathrm{W}$., at an angle of $15^{\circ}$; and as we go up the Water of Ayr, from newer to older beds, we see a great change taking place in the nature of the deposits.

The lowest strata of the sandstones are soft, and rest upon a thick series of breccias, which in appearance are like those at the south entrance of the Drumlanrig tunnel, and consist of angular fragments of amygdaloid, in the cavities of which are nests of zeolitic minerals. In the highest portions of these breccias there are thin beds of a siliceous limestone, of a purplish colour, but in these I found no organic remains. See Section, fig. 4. In going up the stream, from

Fig. 4.-Section near Ballochmoyle, Water of Ayr, Ayrshire.

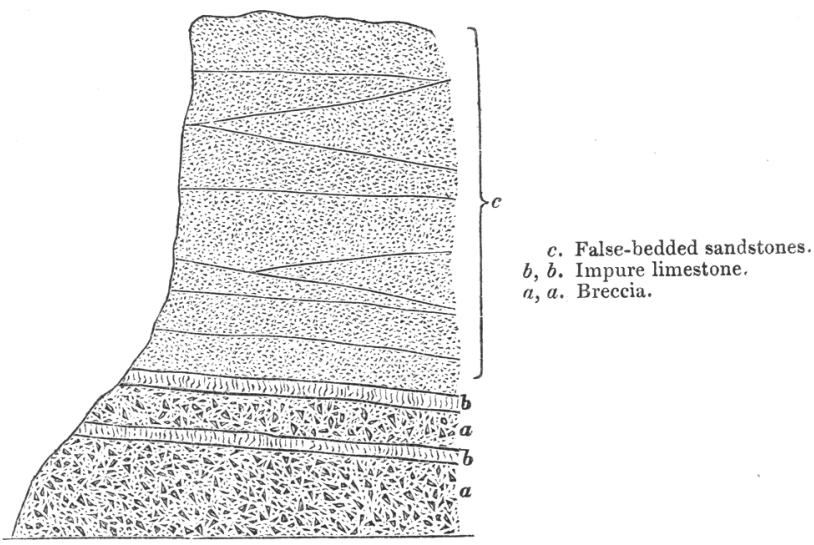

the higher to the lower beds of the breccia, we come upon a trapdike which cuts off the beds, and from which the fragments entering into the composition of the breccias have been obtained; and on the eastern side of the dike we have Carboniferous grits, similar to those which surround the sandstones of the Thornhill area.

The association of the several rocks here is intimately connected with what is seen at the entrance of the Drumlanrig tunnel, the only difference being that at Ballochmoyle we have a more perfect section 
presented to us. As regards the thickness of the sandstones, there are more than 200 feet exposed in the Water of Ayr; and the portion of the breccias which is seen must be nearly 50 feet in thickness. The newer strata here exposed appear to me to be most probably the representatives of the low breccias and overlying sandstones of the typical area, Corncockle.

Sandstone-area of Dumfries.-We have now to return to the area already described $*$,- the Dumfries area; not for the purpose of alluding to it in detail, but to endeavour to find out its relation to the several patches which have been noticed. In the memoir referred to, the Locharbrigs quarries are noticed (loc. cit. p. 391). These are the quarries which are nearest to the Corncockle quarry; and some of the strata seen in them are identical with those at the latter locality, afford the same chelonian footsteps, and have even the same angle of dip and direction. Like the Corncockle strata, they have no breccias covering them, and any person examining the two localities would arrive at the conclusion that they are the same, not only in nature, but position. We have in the Dumfries area no exposures of the beds which are subjacent to these sandstones, and consequently the breccias which support these are not seen.

If the sandstones of the Corncockle quarry and the Locharbrigs strata are the same (which I believe to be the case), then we become possessed of a clue which enables us to judge of the connexion existing between the other beds of the Dumfries patch and those already alluded to.

The Craigs quarry, south-east from Dumfries, is in the line of the strike of the Locharbrigs sandstones. It is similar in its nature, and it affords the same footprints. As we go from Locharbrigs to this quarry, the breccias come on, and are well seen vccupying a position above the sandstone at Craigs (see Section, fig. 5, p. 264); and, consequently, we have in some portions of the Dumfries area certain breccias which have no equivalents occupying the same relative positions in any of the other Dumfriesshire areas, nor in that of Mauchline in Ayrshire.

These higher breccias differ from the lower ones in their nature;they have fewer beds of sandstone interstratified in them, and they are much harder in their composition than the inferior breccias.

It is by no means improbable that the hard flagstones of Templand quarry, which overlie the beds of Corncockle quarry, may be the equivalents of the lower portion of the Craigs breccias, which are fully described in the memoir above referred to $\dagger$. If such be the case, and if the sandstones of Locharbrigs, Craigs, and other localities in the Dumfries area be the equivalents of the beds at the Corncockle quarry, then it follows that the sandstones and breccias newer than the Carboniferous formation can be divided into four distinct groups ;-1st, and lowest, breccias and sandstones, best seen in the course of the Kinnel Water and at Ballochmoyle in Ayrshire; 2nd, sandstones, for the most part false-bedded, well seen in

* Quart. Journ. Geol. Soc, vol. vi. p. 389.

$\uparrow$ Loc. cit. p. 394. 
PROCEEDINGS OF THE GEOLOGICAL SOCIETY. [Mar. 19,

the Corncockle area, the Thornhill district, at Mauchline, and in the neighbourhood of Dumfries; 3rd, hard thick breccias, best seen at the Craigs, Dumfries ; and 4th, thin-bedded sandstone, only slightly developed; occurring at Castledikes, Dumfries, above the breccias*. The Dumfries area presents, so far as can be seen, the same physical geology as the other patches; it appears to dip from the higher hills, and forms a trough through which the River Nith flows.

Since my memoir on the New Red Sandstone of the southern portion of the Vale of the Nith was written, there has been another quarry opened immediately under the south-eastern end of the Maiden-Bower Craigs. See Section, fig. 5. Among the sandstones of

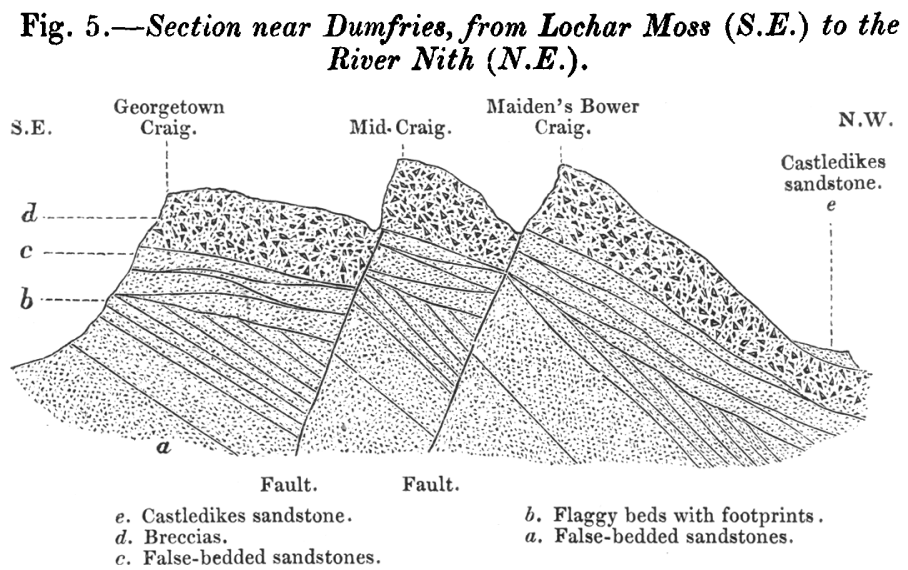

this quarry, which occupy a higher position than those in which the footsteps occur, there are seen features which, so far as I am aware, are peculiar to this spot. The lithological characters of some of the strata here show their intimate connexion with the overlying breccias, since some of the beds have fine breccias mixed up among them. On the surfaces of a few of the higher of these sandstones we have singular markings, which, at first sight, are so remarkable that there is a difficulty in knowing what to make of them. They consist of sunken impressions on the upper faces of the beds. These markings are in some cases somewhat rhomboidal in form, with sharp angles. In other cases they have a rib-like appearance; sometimes they are sinuous, and at other times they are cylindrical; and might be taken for either portions of stems of trees, or fragments of large Orthocerata. I was at one time disposed to regard them as the result of a peculiar mode of rippling, such as would arise from the action of a small rill over a muddy beach; but the angular character of some of the markings is hostile to this opinion; and the cylindrical form which they sometimes present is also opposed to this idea. I am indebted to my friend Sir William Jardine for the correct explanation as to

* Loc. cit. p. 396. 
the nature of these singular markings; some of the most beautiful having been sent to him and being now in his possession. They are a unique form of desiccation-cracks, produced on mud which, in consequence of exposure to solar rays after the cracking, has curled up at the edges in some instances; and this curling has sometimes proceeded so far as to cause the mud to assume almost the form of a hollow cylinder, into which the sand has been afterwards poured; and in consequence we have the stem-like forms which occur in these sandstones. Sir W. Jardine informs me that he has seen modifications of the same circumstances which produced these singular markings take place on the banks of the River Annan among the muds which have been deposited during freshets.

These markings are not the only impressions which the sandstones of the Maiden-Bower afford. We frequently find on the upper surfaces of the strata pitted hollows; and we have natural casts of these on the under side of the overlying beds. On an average, the length of these impressions is about $\frac{3}{4}$ of an inch, and their breadth about $\frac{5}{12}$ of an inch, so that they have a form approaching to oval. They have a deeper impression on one end than the other, which gradually thins out; and these deeper impressions are all in the same direction on one surface. I was at first inclined to regard them as resulting from rain-drops; but they are larger and more irregular than the pittings produced by either rain or hail ; and Sir Charles Lyell, who had an opportunity of examining this quarry with me, suggested that they might be caused by the splashing of spray driven almost horizontally on a muddy shore. Their elongated form shows that the force causing them had a less perpendicular direction than rain, and spray driven by the wind from the sea appears to have been their origin*.

If the singular markings already alluded to be the result of desiccation, and if these irregular oval markings owe their occurrence to spray, then we have on these ancient shores proofs of a hot sun's rays falling on a muddy beach, and proofs of the lashings of the sea by a violent wind which drove the tops of the foam-crested waves in the form of spray on this old beach.

Isolation of the Sandstone-areas.-The isolated position of the several sandstone-areas is a subject which next presents itself. Looking at these patches on the map, and knowing that some of them are surrounded by lofty mountains, it will at once be perceived that they could not have been deposited singly in the several areas which they occupy.

The intimate connexion which exists in the lithological characters of the series of beds forming these patches, shows that they have had a much more intimate union than they now possess; and all the circumstances lead to the inference that they are the relics of a large mass of sandstones and breccias which at one time covered a great portion of the South of Scotland; and which has been to a very great extent removed from the surface of the upturned Silurians by denuda-

* Original sketches of these markings and of the desiccation-cracks are deposited in the Society's Library.-ED. 
tion. At what period this denudation took place we have no means of determining; but a considerable amount of destruction must have occurred during the pleistocene period; for the beds which represent this formation in some portions of the South of Scotland consist almost exclusively of sand and gravel, the former of which has been derived from the abraded sandstone, whilst in the latter we have sometimes fragments of the higher breccia. It is, however, on the whole probable that the sandstones and their accompanying strata had suffered a great amount of denudation at a period antecedent to the glacial epoch.

Previously to this denudation, it would appear that there existed over an area which is now exclusively occupied by Silurians and Carboniferous rocks, thick deposits of a newer age, having their lower beds composed of breccias and intercalated sandstones; above which were red sandstones greatly false-bedded; succeeded by hard breccias ; the only remains of which in Scotland are to be found in the neighbourhood of Dumfries, and thin-bedded sandstones, of which only slight traces now remain. The preservation of the isolated patches seems to have resulted from subsidences which have dragged down into hollows these newer strata, the harder Silurians on their margins protecting them from total destruction.

Age of the Sandstones and Breccias.-With respect to the age of the sandstones and breccias of the South of Scotland newer than the Carboniferous formation, - we have as yet obtained from them no fossils which will enable us to co-ordinate them with deposits of a like nature elsewhere. Such evidence of the existence of animals as they possess is not capable of affording us much assistance, since the footsteps obtained from the sandy strata seem to be unique among sedimentary deposits; therefore no definite conclusions can be drawn from them. We are consequently under the necessity of adopting lithological evidence in this matter. Red sandstones similar in all respects to those described are common to many parts of the Trias of England; but we do not find these red sandstones succeeded by thick beds of breccia, as is the case with those under consideration. Breccias are rare among the Trias, while conglomerates abound in some of the middle and lower beds. We have, however, no conglomerates in the Scotch red sandstones; the absence of conglomerates and the presence of breccias show that the lithological characters of the strata will not support the conclusion that these deposits are of the Triassic age.

We are therefore under the necessity of comparing them with another formation which affords red sandstones. In the Permian series we have sandstones which bear resemblance to those of the South of Scotland. Here likewise we have breccias ; and Mr. Binney has shown * that in the neighbourhood of Brough and Kirkby Stephen, in Westmoreland, the associations and composition of the strata closely resemble those of the deposits in the neighbourhood of Dumfries, so much so, that he concludes the deposits of Westmore-

* Memoirs of the Literary and Philosophical Society of Manchester, vol. xii. p. $257 \&$ p. 267. 
land and the Craigs near Dumfries to be of the same age. Sir Charles Lyell and myself had an opportunity of examining the Westmoreland strata above referred to, and can acquiesce in the conclusions concerning relative position and mineral character. Sir Roderick Murchison had some years before adopted the opinion of the Permian age of the Dumfries series*, and was the first to announce this view. Mr. Binney also, when he accompanied me several years ago to the Craigs, seemed disposed to question the Triassic age of the strata there exposed; and on this occasion, when we visited the quarry at Green Mill in the parish of Caerlaverock, where beds similar to those of the Craigs quarry, and occupying the same position, are worked, he was the first to detect footprints. These impressions he stated were different from any found by him in the Trias of Cheshire.

Resting the conclusions therefore on the mineral evidence, it would appear that the sandstones which have hitherto generally been regarded as of Triassic age must be referred to the Permian; and probably the only portion of Triassic sandstone which occurs in the South of Scotland is that extending from Cumberland into the southeast of Dumfriesshire, the association of the strata of which is entirely different from that in the several areas described.

The existence of animal life, in the form of Reptiles, during the period of the deposition of these Permian beds must have been abundant, since we meet with numerous impressions caused by Chelonians, Lizards, and Batrachians, which walked over the shores of the Permian Sea when its sandstones were sandy beaches with mudpatches scattered over them.

* Quart. Journ. Geol. Soc. vol. vii. p. 163. 